(NASA-TM-111196) CHEMICAL

STABILITY OF THE FIBER

COATING/MATRIX INTERFACE IN

SILICON-BASED CERAMIC MATRIX

COMPOSITES (NASA. Lewis Research

Center) $5 p$
N96-17776

Unclas

G3/27 0098245 


\title{
Chemical Stability of the Fiber Coating/Matrix Interface in Silicon-Based Ceramic Matrix Composites
}

\author{
Kang N. Lee ${ }^{* \dagger}$ and Nathan S. Jacobson \\ NASA Lewis Research Center, Cleveland, Ohio 44135
}

Carbon and boron nitride are used as fiber coatings in silicon-based composites. In order to assess the long-term stability of these materials, reactions of carbon $/ \mathrm{Si}_{3} \mathrm{~N}_{4}$ and $\mathrm{BN} / \mathrm{SiC}$ were studied at high temperatures with Knudsen effusion, coupon tests, and by microstructural examination. In the carbon/ $\mathrm{Si}_{3} \mathrm{~N}_{4}$ system, carbon reacted with $\mathrm{Si}_{3} \mathrm{~N}_{4}$ to form gaseous $\mathrm{N}_{2}$ and $\mathrm{SiC}$. The formation of $\mathrm{SiC}$ limited further reaction by physically separating the carbon and $\mathrm{Si}_{3} \mathrm{~N}_{4}$. Consequently, the development of high $p\left(\mathrm{~N}_{2}\right)$ at the interface, predicted from thermochemical calculations, did not occur, thus limiting the potential deleterious effects of the reaction on the composite. Strong indications of a reaction between $\mathrm{BN}$ and $\mathrm{SiC}$ were shown by TEM and SIMS analysis of the $\mathrm{BN} / \mathrm{SiC}$ interface. In long-term exposures, this reaction can lead to a depletion of a $\mathrm{BN}$ coating and/or an unfavorable change of the interfacial properties, limiting the beneficial effects of the coating.

\section{Introduction}

Giber-Reinforced ceramic composites are an emerging class - of high-temperature structural materials. This is primarily due to their potential for enhanced mechanical properties, such as fracture toughness and strength, and the resultant increased reliability as structural components. However, one of the key areas to be critically addressed for the realization of the full potentials of composites is the fiber/matrix interface. The interface must be chemically stable. In addition, in systems where the matrix is brittle, the fiber/matrix interface bonding has to be optimized to promote the load transfer from the matrix to the fibers and to permit the matrix microcrack deflection. ${ }^{1}$ One approach to optimize interfacial properties is to apply fiber coatings.

Some of the most promising composites for high-temperature structural applications are $\mathrm{SiC}$ fiber $/ \mathrm{Si}_{3} \mathrm{~N}_{4}$ matrix and $\mathrm{SiC}$ fiber/SiC matrix systems. To limit fiber/matrix bonding, the fibers are coated with carbon or boron nitride (BN). In the event of matrix cracking, these coatings will readily oxidize; however, this issue is beyond the scope of this paper and has been treated in detail elsewhere. ${ }^{2-4}$

Ideally, the matrix will not crack and the interface will remain at a low oxygen potential for long times. The purpose of this paper is to investigate the chemical stability of the interface coating in $\mathrm{SiC}$ fiber/SiC matrix and $\mathrm{SiC}$ fiber/ $\mathrm{Si}_{3} \mathrm{~N}_{4}$ matrix systems and its implication on the long-term durability of these composites.

R. Naslain-contributing editor
II. Thermodynamic Considerations

\section{(1) Carbon $/ \mathrm{Si}_{3} \mathrm{~N}_{4}$ System}

Carbon can react with $\mathrm{Si}_{3} \mathrm{~N}_{4}$ according to reaction (1), producing $\mathrm{N}_{2}(g)$ and $\mathrm{SiC}(s)$.

$$
\mathrm{Si}_{3} \mathrm{~N}_{4}+3 \mathrm{C}=3 \mathrm{SiC}+2 \mathrm{~N}_{2}(g)
$$

Some $\mathrm{N}_{2}(g)$ can also be generated by the vaporization of $\mathrm{Si}_{3} \mathrm{~N}_{4}$.

$$
\mathrm{Si}_{3} \mathrm{~N}_{4}=3 \mathrm{Si}+2 \mathrm{~N}_{2}(g)
$$

The SOLGASMIX-PV program ${ }^{5}$ in conjunction with JANAF thermochemical data ${ }^{6}$ was used to calculate $p\left(\mathrm{~N}_{2}\right)_{\text {eq }}$ for reactions (1) and (2) as shown in Fig. 1. Note that $p\left(\mathrm{~N}_{2}\right)_{\mathrm{eq}}$ is independent of the $\mathrm{Si}_{3} \mathrm{~N}_{4} / \mathrm{C}$ ratio, although the calculation was carried out for a 1:1 mixture. The reaction between carbon and $\mathrm{Si}_{3} \mathrm{~N}_{4}$ substantially increased $p\left(\mathrm{~N}_{2}\right)_{\mathrm{eq}}$ when compared to $p\left(\mathrm{~N}_{2}\right)_{\mathrm{eq}}$ in pure $\mathrm{Si}_{3} \mathrm{~N}_{4}$. The formation of nitrogen gas at pressures near $10^{5} \mathrm{~Pa}$ within the composite may cause some internal damage. If nitrogen has a route for escape, such as a microcrack or pore, the carbon coating will be depleted.

\section{(2) BN/SiC System}

The potential reactions between $\mathrm{BN}$ and $\mathrm{SiC}$ include

$$
\begin{aligned}
& \mathrm{SiC}+4 \mathrm{BN}=\mathrm{B}_{4} \mathrm{C}+\mathrm{Si}(g)+2 \mathrm{~N}_{2}(g) \\
& 3 \mathrm{SiC}+12 \mathrm{BN}=\mathrm{Si}_{3} \mathrm{~N}_{4}+3 \mathrm{~B}_{4} \mathrm{C}(s)+4 \mathrm{~N}_{2}(g) \\
& \mathrm{C} \text { (excess } \mathrm{C} \text { in } \mathrm{SiC})+4 \mathrm{BN}(s)=\mathrm{B}_{4} \mathrm{C}+2 \mathrm{~N}_{2}(g)
\end{aligned}
$$

Some $\mathrm{N}_{2}(g)$ and $\mathrm{Si}(g)$ can be generated by the vaporization of $\mathrm{BN}$ and $\mathrm{SiC}$, respectively.

$$
\begin{aligned}
& \mathrm{BN}=\mathrm{B}+\frac{1}{2} \mathrm{~N}_{2}(g) \\
& \mathrm{SiC}=\mathrm{Si}(g)+\mathrm{C}
\end{aligned}
$$

Figure 2 compares $p\left(\mathrm{~N}_{2}\right)_{\mathrm{eq}}+p(\mathrm{Si})_{\mathrm{eq}}$ in the reacted $\mathrm{SiC} / \mathrm{BN}$

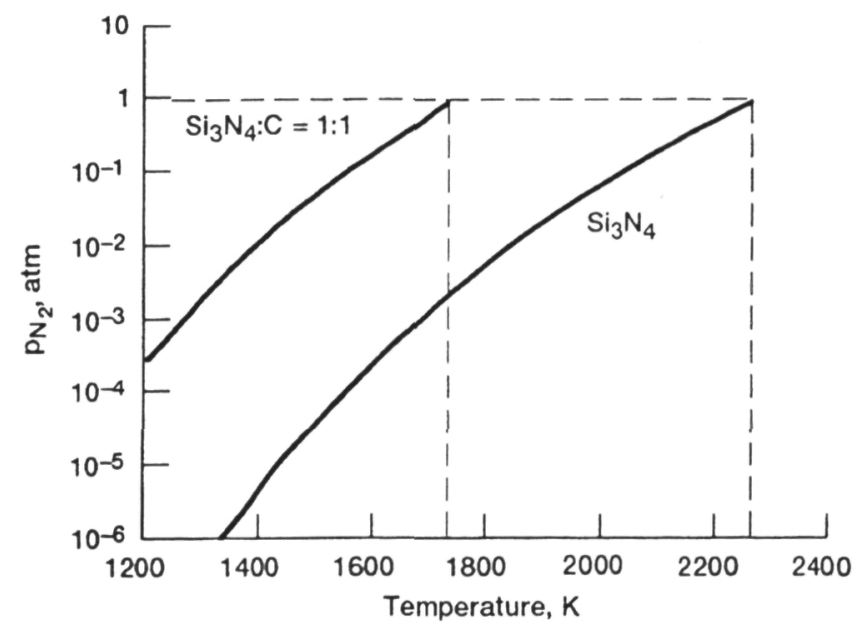

Fig. 1. Calculated pressure of $\mathrm{N}_{2}(g)$ for $\mathrm{Si}_{3} \mathrm{~N}_{4}$ and the carbon/ $/ \mathrm{Si}_{3} \mathrm{~N}_{4}$ system.
Manuscript No. 193754. Received March 14, 1994; approved October 11, 1994

Member, American Ceramic Society

${ }^{\dagger}$ Resident Research Associate from Cleveland State University, Cleveland, OH. 


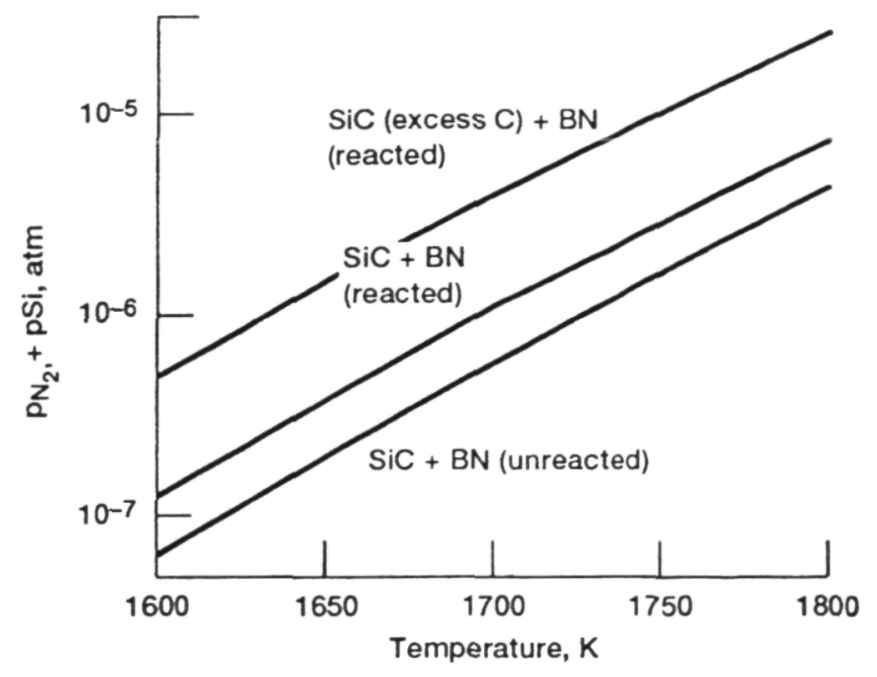

Fig. 2. Calculated pressure of $\mathrm{N}_{2}(g)+\mathrm{Si}(g)$ for the reacted and unreacted $\mathrm{BN} / \mathrm{SiC}$ system.

system with that in the unreacted $\mathrm{SiC} / \mathrm{BN}$ system. The reaction of $\mathrm{BN}$ with $\mathrm{SiC}$ or excess carbon in $\mathrm{SiC}$ slightly increased the total gaseous pressure, indicating that limited reactions between $\mathrm{BN}$ and $\mathrm{SiC}$ occur. However, the pressure is so low that the reaction is not likely to cause any mechanical instability to the $\mathrm{SiC}$ fiber/SiC matrix composites utilizing $\mathrm{BN}$ fiber coating. Nevertheless, the BN coating can be depleted if escape routes for $\mathrm{N}_{2}$ form. Another potential reaction is the formation of a $\mathrm{BN}-\mathrm{C}$ solid solution, $(\mathrm{BN})_{x} \mathrm{C}_{1-x}{ }^{7.8}$ With a carbon-rich $\mathrm{SiC}$ matrix, this may lead to eventual diffusion of the $\mathrm{BN}$ coating into the substrate.

\section{Experimental Procedure}

Knudsen effusion and coupon tests were employed in this study to investigate the reactions at the carbon/ $\mathrm{Si}_{3} \mathrm{~N}_{4}$ and $\mathrm{BN} /$ $\mathrm{SiC}$ interfaces. Knudsen effusion was done with powders to obtain information on the gaseous and solid products. Coupon studies provided further information on the solid products.

\section{(1) Knudsen Effusion Test}

Knudsen effusion is a classic technique for the study of equilibrium between condensed and gaseous phases. ${ }^{9}$ Intimately mixed powders of reactants are placed in the Knudsen

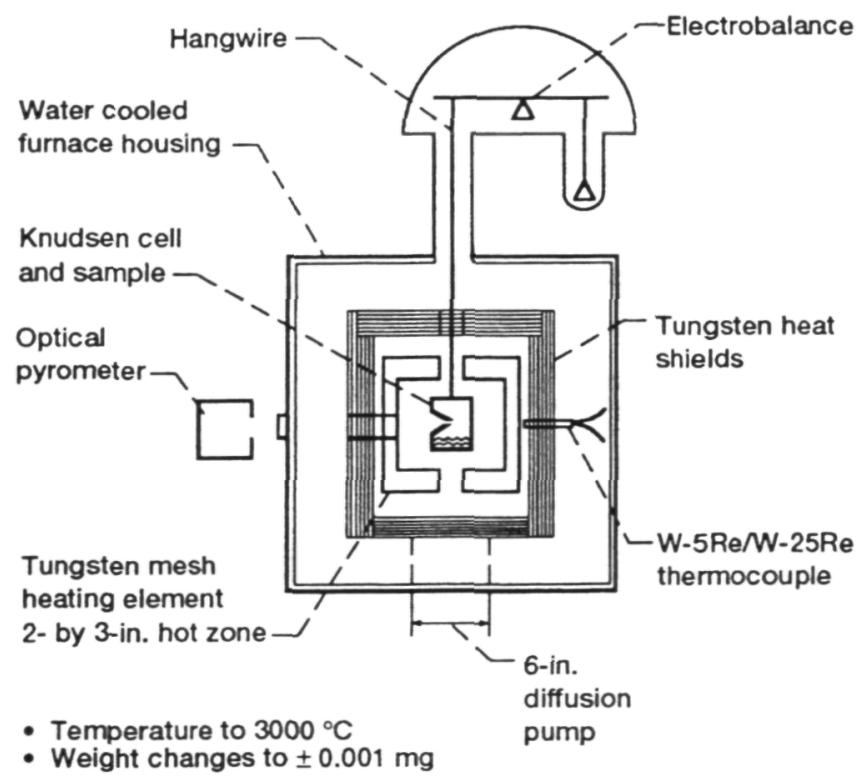

Fig. 3. Schematic of vacuum thermogravimetric apparatus in conjunction with a Knudsen cell.

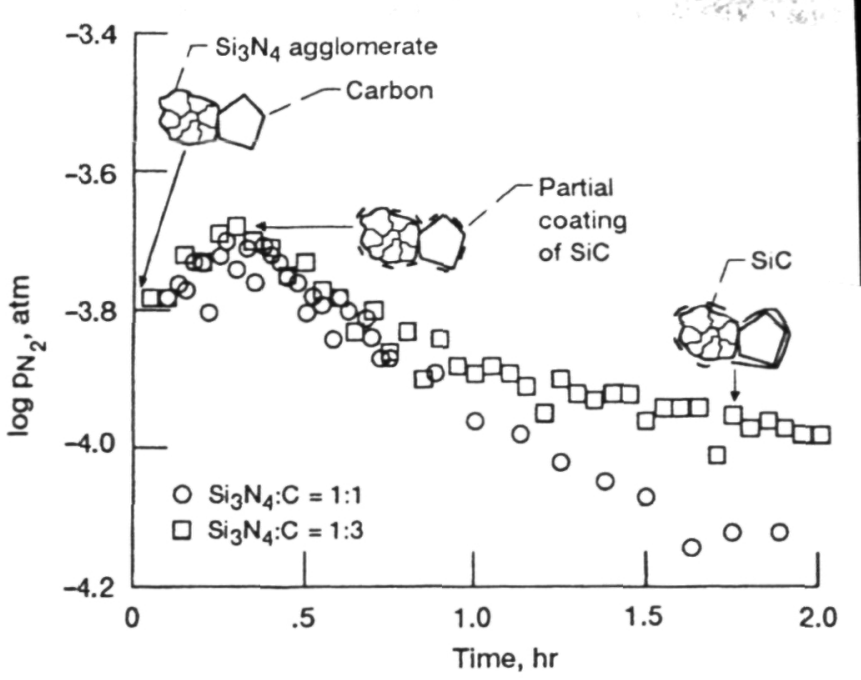

Fig. 4. Pressure of $\mathrm{N}_{2}(\mathrm{~g})$ for the carbon $/ \mathrm{Si}_{3} \mathrm{~N}_{4}$ system at $1600 \mathrm{~K}$ determined by the Knudsen effusion test.

cell with a small orifice and heated up to a reaction temperature in a vacuum. If the orifice is sufficiently small, equilibrium is established inside the cell. The effusion rate of gaseous reaction products through the orifice is measured with a microbalance, as shown in Fig. 3. The resolution of the microbalance/Knudsen cell system is $\pm 0.001 \mathrm{mg}$. From the effusion rate, the total vapor pressure is calculated using the Hertz-KnudsenLangmüir equation. ${ }^{9}$

$$
\begin{aligned}
P & =(\mathrm{d} w / \mathrm{d} t)(1 / A)(2 \pi R T / M)^{1 / 2} \\
& =6.27 \times 10^{-6}(\mathrm{~d} w / \mathrm{d} t)(1 / A)(T / M)^{1 / 2}
\end{aligned}
$$

Here $P$ is vapor pressure in atm, $\mathrm{d} W / \mathrm{d} t$ is mass effusion rate in $\mathrm{g} / \mathrm{h}, A$ is orifice area in $\mathrm{cm}^{2}, T$ is absolute temperature, $R$ is the gas constant, and $M$ is the weighted average molecular weight of the vapor species. Details of the experimental setup are described elsewhere. ${ }^{10}$ Previous work has demonstrated that the Knudsen effusion technique can be applied to a detailed study of interfacial reactions. ${ }^{10}$

It is critical that Knudsen cell materials be inert to both the reactants and the products. We found that graphite and molybdenum were adequate for carbon/ $\mathrm{Si}_{3} \mathrm{~N}_{4}$ reaction and $\mathrm{BN} /$ $\mathrm{SiC}$ reaction, respectively. It appears that the molybdenum cell forms a protective inner coating of $\mathrm{MoSi}_{2}$ which is inert to the $\mathrm{BN} / \mathrm{SiC}$ mixture. Therefore, prior to the investigation of the $\mathrm{BN} / \mathrm{SiC}$ reaction, preliminary runs to form $\mathrm{MoSi}_{2}$ coating inside the molybdenum cell were carried out. High-purity powders of carbon, $\mathrm{Si}_{3} \mathrm{~N}_{4}, \mathrm{BN}$, and $\mathrm{SiC}$ were used as the reactants. Powder particle diameters varied from 1 to $100 \mu \mathrm{m}$ for carbon and 10 to $150 \mu \mathrm{m}$ for $\mathrm{Si}_{3} \mathrm{~N}_{4}, \mathrm{SiC}$, and $\mathrm{BN}$, which were agglomerates of finer particles with $0.1-1 \mu \mathrm{m}$ diameter. After testing, powders were examined by X-ray diffraction (XRD), scanning electron microscopy (SEM), transmission electron microscopy (TEM), and energy dispersive spectroscopy (EDS).

\section{(2) Coupon Test}

Coated coupons were employed to closely simulate the condition at the fiber/matrix interface and provide additional information on any solid products formed. Chemically vapordeposited (CVD) $\mathrm{Si}_{3} \mathrm{~N}_{4}$ and $\mathrm{SiC}$ coupons $(1 \mathrm{~cm} \times 1 \mathrm{~cm} \times 0.2$ $\mathrm{cm})$ were polished to $1 \mu \mathrm{m}$ with diamond paste, and any residual surface $\mathrm{SiO}_{2}$ was dissolved in $10 \% \mathrm{HF}$. Carbon $(0.1 \mu \mathrm{m}$ thick) and $\mathrm{BN}(0.3 \mu \mathrm{m}$ thick $)$ were deposited on the polished surface of $\mathrm{Si}_{3} \mathrm{~N}_{4}$ and $\mathrm{SiC}$ using a spark coater and CVD, respectively. After the coated coupons were heat treated under vacuum $\left(6.7 \times 10^{-5} \mathrm{~Pa}\right)$ at high temperatures $\left(1650 \mathrm{~K}\right.$ for $\mathrm{C} / \mathrm{Si}_{3} \mathrm{~N}_{4}$ and $1730 \mathrm{~K}$ for $\mathrm{BN} / \mathrm{SiC}$ ), the coating/substrate interface was analyzed with TEM and secondary ion mass spectrometry (SIMS). 

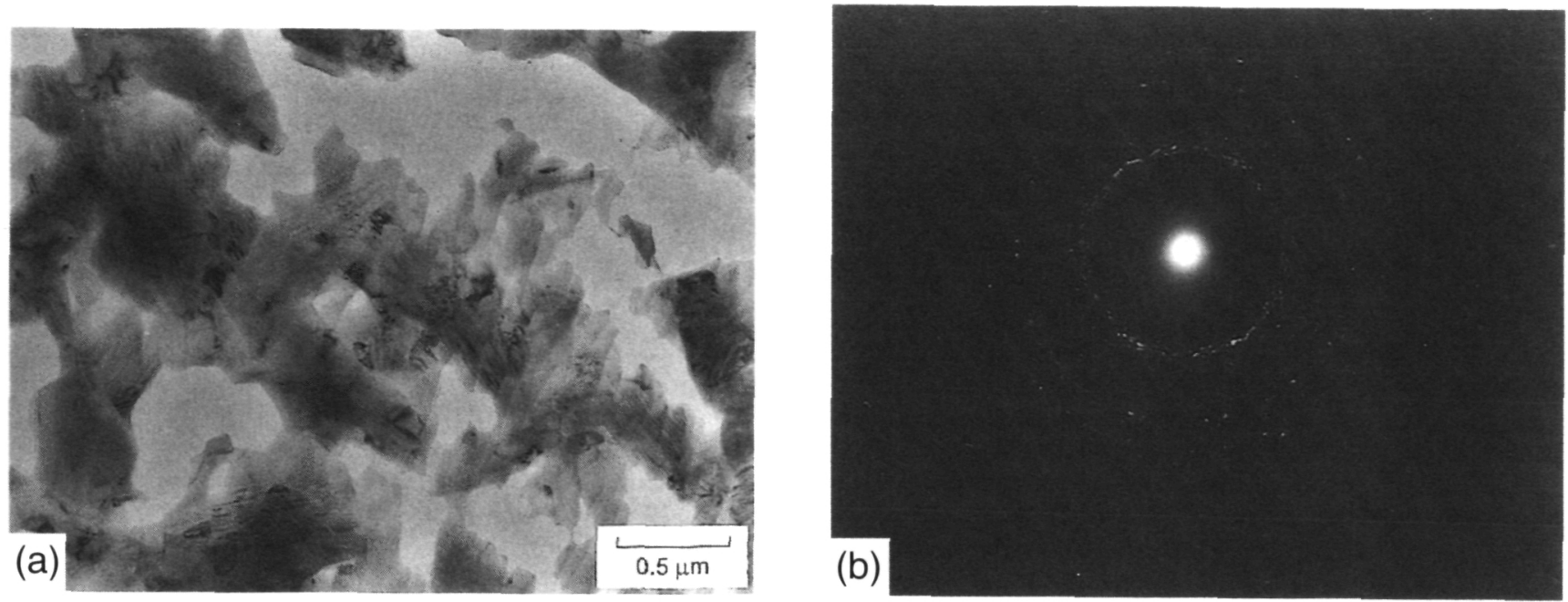

Fig. 5. TEM analysis of the carbon/ $\mathrm{Si}_{3} \mathrm{~N}_{4}$ interface for a carbon-coated $\mathrm{Si}_{3} \mathrm{~N}_{4}$ coupon after $45 \mathrm{~h}$ under vacuum at $1650 \mathrm{~K}$. (a) TEM image. (b) Electron diffraction pattern.

\section{Results and Discussion}

\section{(1) Carbon $/ \mathrm{Si}_{3} \mathrm{~N}_{4}$ System}

Figure 4 shows $p\left(\mathrm{~N}_{2}\right)$ for the $\mathrm{Si}_{3} \mathrm{~N}_{4} / \mathrm{C}$ reaction determined from Knudsen effusion tests at $1600 \mathrm{~K}$. The $p\left(\mathrm{~N}_{2}\right)$ initially increased until it reached the maximum pressure after about $15 \mathrm{~min}$. It remained constant for about $10-15 \mathrm{~min}$ and then decreased gradually. Mixtures with a lower $\mathrm{C} / \mathrm{Si}_{3} \mathrm{~N}_{4}$ ratio exhibited a more rapid decrease of $p\left(\mathrm{~N}_{2}\right)$. EDS showed a high silicon concentration on carbon particles after $2 \mathrm{~h}$, which was due to the $\mathrm{SiC}$ formed by reaction (1) as was identified by XRD. The EDS silicon peak was significant by $30 \mathrm{~min}$, although XRD did not show $\mathrm{SiC}$ peaks until later. It appears that $\mathrm{SiC}$ already formed by $30 \mathrm{~min}$, but its amount was below the resolution of $\mathrm{XRD}$. The formation of $\mathrm{SiC}$ on carbon particles as early as $30 \mathrm{~min}$ and the gradual decrease of $p\left(\mathrm{~N}_{2}\right)$ after the maximum at 15-30 min indicate that $\mathrm{SiC}$ caused the gradual decrease of $p\left(\mathrm{~N}_{2}\right)$ by separating the carbon and the $\mathrm{Si}_{3} \mathrm{~N}_{4}$, thus acting as a physical reaction barrier.

Coupon tests also confirmed the formation of $\mathrm{SiC}$ at the $\mathrm{C} /$ $\mathrm{Si}_{3} \mathrm{~N}_{4}$ interface. After a heat treatment in $6.7 \times 10^{-7} \mathrm{~Pa}$ at $1650 \mathrm{~K}$ for $45 \mathrm{~h}$, the coating on the $\mathrm{Si}_{3} \mathrm{~N}_{4}$ coupon was completely delaminated. The delamination presumably occurred during the cooling, due to the coefficient of thermal expansion (CTE) mismatch at the interface. The TEM image and electron

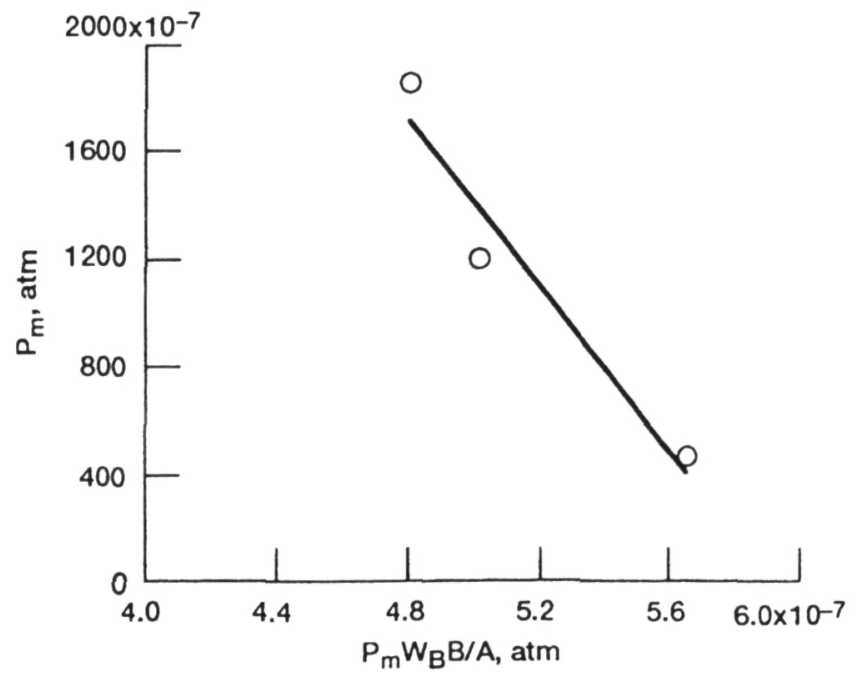

Fig. 6. Whitman-Motzfeldt extrapolation of $p\left(\mathrm{~N}_{2}\right)$ for the carbon/ $\mathrm{Si}_{3} \mathrm{~N}_{4}$ system at $1600 \mathrm{~K}$. diffraction pattern of the interface are shown in Fig. 5. The electron diffraction ring pattern matches that of $\beta$-SiC, confirming the formation of a polycrystalline $\beta$-SiC.

In a recent study employing fiber push-out and fracture tests, in conjunction with Auger electron spectrometry (AES) depth profiles, $\mathrm{SiC}$ was not detected at the interface of a carboncoated $\mathrm{SiC}$ fiber/reaction-bonded $\mathrm{Si}_{3} \mathrm{~N}_{4}$ matrix composite processed at $1473 \mathrm{~K}$ in $1 \mathrm{~atm} \mathrm{~N}_{2} .{ }^{11}$ It should be noted, however, that the carbon $/ \mathrm{Si}_{3} \mathrm{~N}_{4}$ interface was at 1 atm $p\left(\mathrm{~N}_{2}\right)$ during the processing because the matrix has a porosity of $35 \% .{ }^{12}$ Since the $p\left(\mathrm{~N}_{2}\right)_{\text {eq }}$ for reaction (1) was less than 1 atm at the processing temperature (see Fig. 1), reaction (1) was effectively suppressed at the interface.

In Knudsen effusion, a dependence of vapor pressure on orifice size implies a kinetic barrier to equilibration. ${ }^{9}$ In such a case, equilibrium pressure can be estimated by extrapolating the measured pressure at various orifice sizes to zero orifice size using the Whitman-Motzfeld equation. ${ }^{13,14}$

$$
P_{\mathrm{m}}=P_{\mathrm{eq}}-\left(1 / a+1 / W_{\mathrm{A}}-2\right) P_{m} W_{B} B / A
$$

Here $P_{\mathrm{m}}$ is the measured pressure, $P_{\mathrm{eq}}$ is the equilibrium pressure, $a$ is the vaporization coefficient, $A$ is the cross-sectional

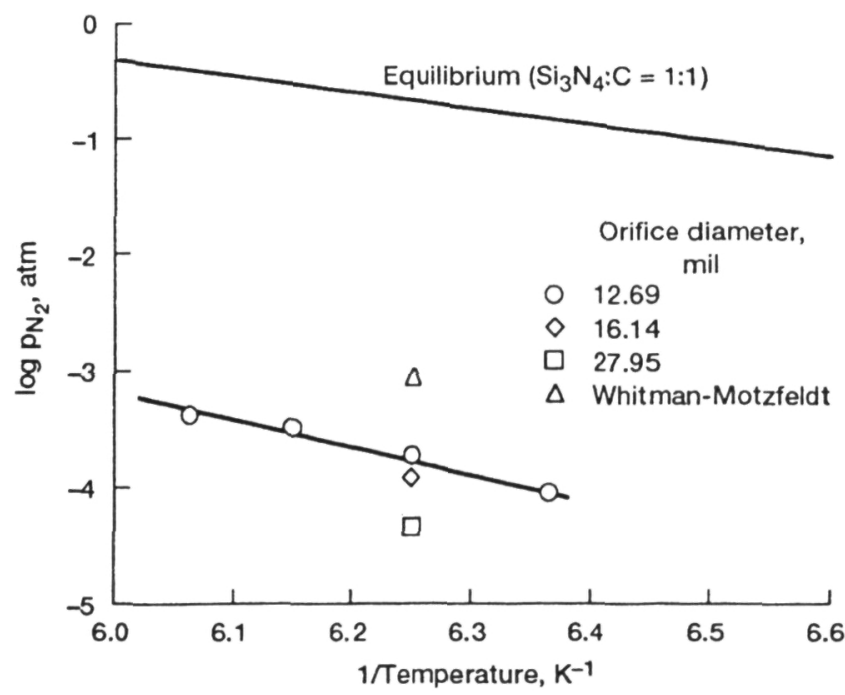

Fig. 7. Steady-state pressure of $\mathrm{N}_{2}(g)$ for the carbon/ $/ \mathrm{Si}_{3} \mathrm{~N}_{4}$ system determined by the Knudsen effusion test. (Steady-state pressure is defined as the maximum pressure of $\mathrm{N}_{2}(g)$ before it gradually decreases as shown in Fig. 4. The duration of steady state becomes longer with decreasing orifice diameter.) 


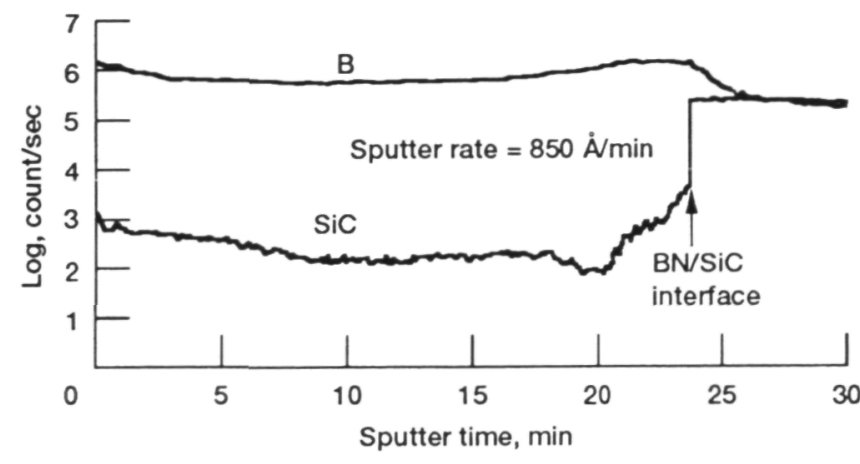

(a)

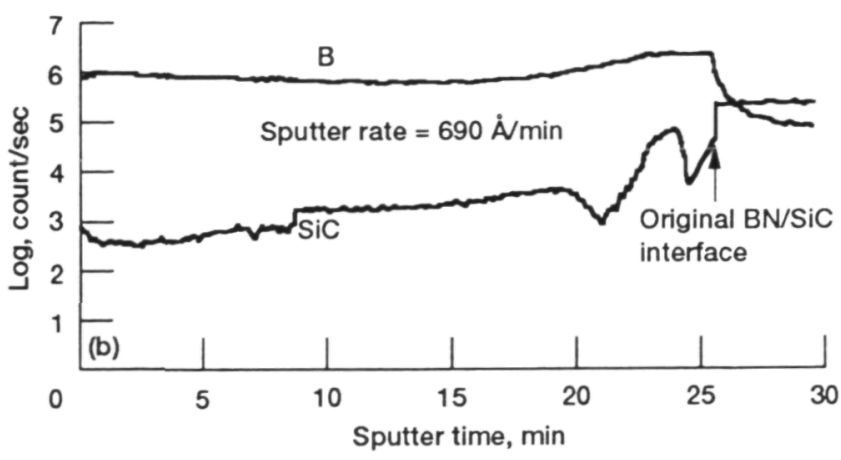

(b)

Fig. 8. SIMS analysis of the BN/SiC interface for a BN-coated SiC coupon. (a) As-coated. (b) After $50 \mathrm{~h}$ under vacuum at $1730 \mathrm{~K}$.

area of the cell $\left(0.316 \mathrm{~cm}^{2}\right), B$ is the orifice area $\left(8 \times 10^{-4} \sim\right.$ $\left.4 \times 10^{-3} \mathrm{~cm}^{2}\right), W_{\mathrm{A}}$ is the Clausing factor of the cell, and $W_{\mathrm{B}}$ is the Clausing factor of the orifice $(\sim 1)$. The Clausing factor is the fraction of molecules escaping through an orifice or channel. Figure 6 is a plot of Whitman-Motzfeld extrapolation (Eq. (6)) to estimate $p\left(\mathrm{~N}_{2}\right)_{\mathrm{eq}}$. Note the dependence of the measured $p\left(\mathrm{~N}_{2}\right)$ on the orifice size, confirming the existence of a kinetic reaction barrier. Figure 7 compares the estimated $p\left(\mathrm{~N}_{2}\right)_{\mathrm{eq}}$ (triangle) with the calculated $p\left(\mathrm{~N}_{2}\right)_{\mathrm{eq}}$. Even after the correction for the chemical reaction barrier, the estimated $p\left(\mathrm{~N}_{2}\right)_{\text {eq }}$ was about two orders of magnitude lower than the calculated $p\left(\mathrm{~N}_{2}\right)_{\mathrm{eq}}$. This discrepancy is too large to be attributed to experimental errors. This indicates that there was another reaction barrier which was not considered in the Whitman-Motzfeld extrapolation. It appears that the $\mathrm{SiC}$ physical reaction barrier formed even before the reaction equilibrium was established, preventing the system from reaching equilibrium.

The heat of reaction can be calculated from the slope of log $\left(K_{\mathrm{p}}\right)$ vs $1 / T$ using the Van't Hoff equation:

$$
d \log \left[p\left(\mathrm{~N}_{2}\right)\right]^{2} / \mathrm{d}(1 / T)=-\Delta H / R
$$

Here $\Delta H$ is the heat of reaction, $T$ is the absolute temperature, and $R$ is a gas constant. The calculated heat of reaction was 895 $\mathrm{kJ} / \mathrm{mol}$, which was much higher than the equilibrium heat of reaction $(530 \mathrm{~kJ} / \mathrm{mol})$. This also indicates that the measured $p\left(\mathrm{~N}_{2}\right)$ was not $p\left(\mathrm{~N}_{2}\right)_{\mathrm{eq}}$.

If the reaction between carbon and $\mathrm{Si}_{3} \mathrm{~N}_{4}$ continued as was thermodynamically predicted, either the coating would be depleted or a high $p\left(\mathrm{~N}_{2}\right)$ would be generated at the interface. However, the $\mathrm{SiC}$ physical reaction barrier prevented further reaction and the resultant development of high $p\left(\mathrm{~N}_{2}\right)$, limiting the predicted deleterious effects of the reaction. Furthermore, the shear property of carbon on $\mathrm{Si}_{3} \mathrm{~N}_{4}$ is similar to that of carbon on $\mathrm{SiC}$, so mechanical properties are not likely to be affected.

\section{(2) BN/SiC System}

No detectable weight loss was measured in the Knudsen effusion test for $\mathrm{BN} / \mathrm{SiC}$ mixture, presumably because the weight loss due to the reactions between $\mathrm{BN}$ and $\mathrm{SiC}$ (reactions $(3 a)-(3 c))$ was below the resolution of the microbalance/Knudsen cell system.

Another possible route for the degradation of the $\mathrm{BN} / \mathrm{SiC}$ interface is the solid-solution reaction between carbon and $\mathrm{BN}$. BN is known to form a solid solution with graphite $\left(\mathrm{BN}_{\mathrm{x}} \mathrm{C}_{1-x}\right)^{7.8}$ The optimum temperature for the formation of the solid solution is $1900^{\circ} \mathrm{C}$, considerably higher than the anticipated application temperature of $\mathrm{SiC} / \mathrm{SiC}$ composites (up to $1500^{\circ} \mathrm{C}$ ). However, there is a driving force to form a solid solution, and over the long term the $\mathrm{BN}$ coating may dissolve in the matrix.
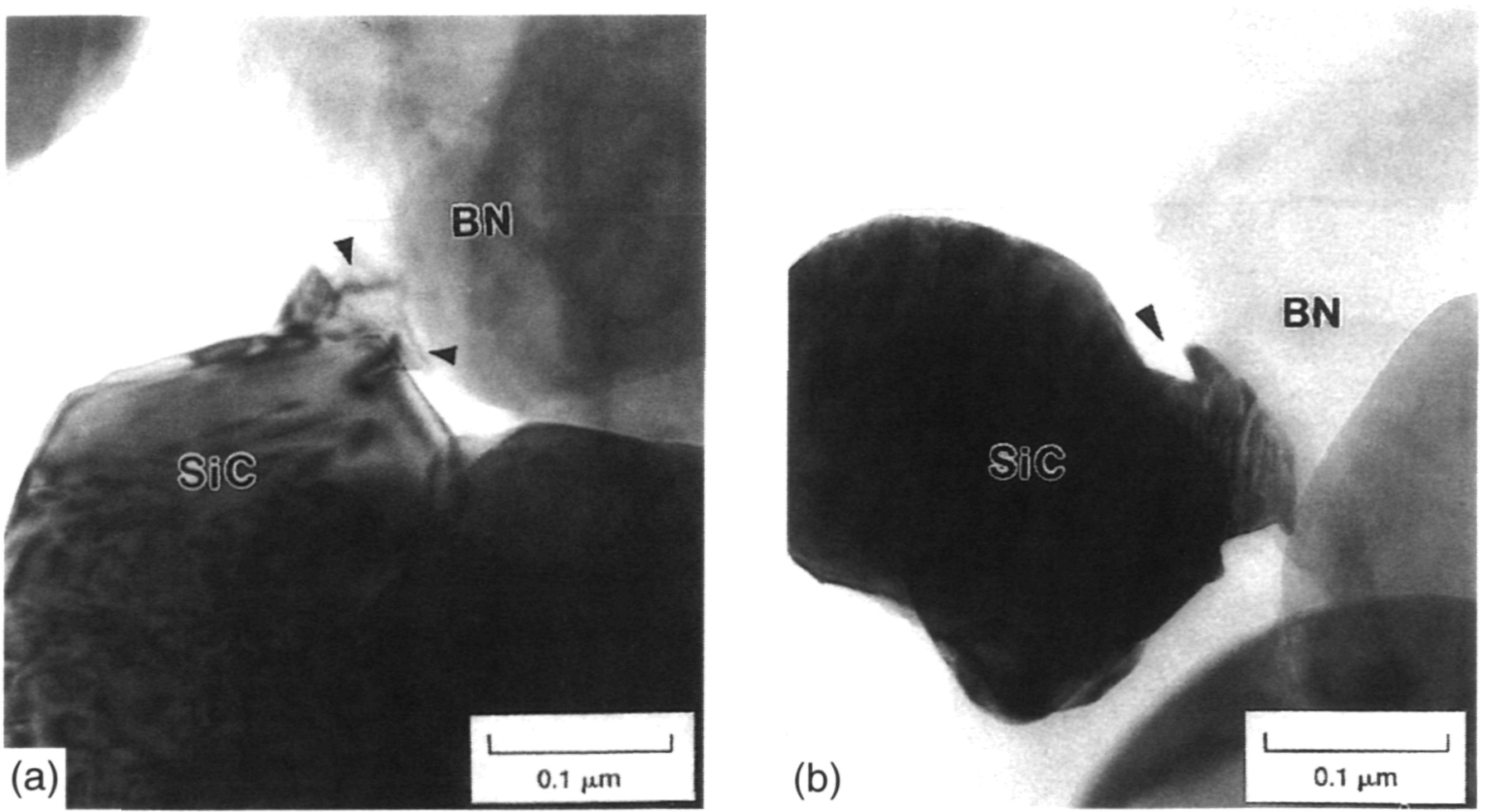

Fig. 9. TEM images of the reaction zone at the $\mathrm{BN} / \mathrm{SiC}$ interface for a $\mathrm{BN}-\mathrm{SiC}$ powder mixture after $170 \mathrm{~h}$ under vacuum at $1770 \mathrm{~K}$. (a) and (b) are from different areas in the same batch. 

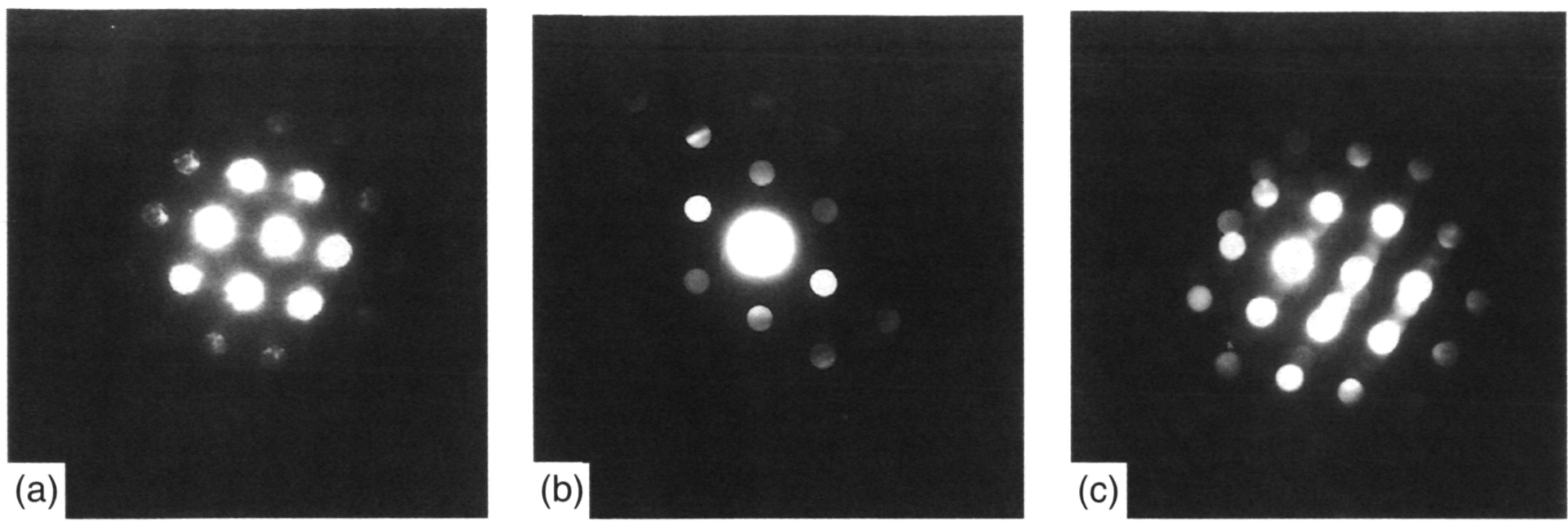

Fig. 10. Microdiffraction patterns at the $\mathrm{BN} / \mathrm{SiC}$ interface for a $\mathrm{BN}-\mathrm{SiC}$ powder mixture after $170 \mathrm{~h}$ under vacuum at $1770 \mathrm{~K}$. (a) $\mathrm{SiC}$. (b) BN. (c) Reaction zone.

Figures 8(a) and (b) are SIMS profiles ${ }^{\ddagger}$ of $\mathrm{SiC}$ and $\mathrm{B}$ in a $\mathrm{BN}$-coated $\mathrm{SiC}$ coupon, as received and heat treated at $1730 \mathrm{~K}$ for $50 \mathrm{~h}$, respectively. A peak in the $\mathrm{SiC}$ count was noticed in the heat-treated sample at the BN coating side of the interface. This feature was not observed in the as-received sample. Its presence suggests the existence of a reaction zone at the interface.

TEM analysis ${ }^{\S}$ of $\mathrm{SiC} / \mathrm{BN}$ powder after the Knudsen effusion test at $1770 \mathrm{~K}$ for $170 \mathrm{~h}$ also showed a reaction zone at the $\mathrm{BN} /$ $\mathrm{SiC}$ interface as shown in Figs. 9(a) and (b). The fringe contours at the $\mathrm{BN} / \mathrm{SiC}$ interface (arrow in Fig. 9(a)) indicate the existence of strain, presumably due to a reaction between $\mathrm{BN}$ and $\mathrm{SiC}$. The reaction zone has grown further in Fig. 9(b) as shown by the arrows. Figures 10(a), (b), and (c) are microdiffraction patterns $(\mu-\mathrm{DP})$ for $\mathrm{SiC}, \mathrm{BN}$, and the reaction zone, respectively. Figure 10 (c) shows only a limited match with the $\mathrm{SiC}$ diffraction pattern. There are clearly many features which are not from $\mathrm{BN}$ or $\mathrm{SiC}$, suggesting the existence of a reaction zone. Further study is needed to identify the reaction product.

The reaction zone can potentially change the interface properties to limit the beneficial effects of the $\mathrm{BN}$ coating. In addition, in a long-term exposure, the $\mathrm{BN}$ layer may eventually be depleted, eliminating the beneficial effects of the coating.

\section{Summary and Conclusions}

Chemical reactions between the fiber coating and matrix materials in silicon-based ceramic matrix composites were investigated. Knudsen effusion was used to investigate gaseous and solid species, and coupon tests were used to simulate the coating/matrix interface and to investigate solid reaction products.

Carbon and $\mathrm{Si}_{3} \mathrm{~N}_{4}$ reacted to form $\mathrm{SiC}$ and $\mathrm{N}_{2}(g)$ as was thermodynamically predicted. Thermodynamic calculations predict that $p\left(\mathrm{~N}_{2}\right)$ reaches 1 atm at $1730 \mathrm{~K}$, which can potentially disrupt the matrix. However, the reaction never reached equilibrium, for the $\mathrm{SiC}$ prevented further reaction and thus reduced $p\left(\mathrm{~N}_{2}\right)$ by three orders of magnitude. As a result, the predicted deleterious effect of the reaction on the composite is likely to be limited.

\footnotetext{
Analysis performed at Perkin Elmer, Eden Prairie, MN.

${ }^{9}$ Analysis performed at R. J. Lee Group, Inc., Berkeley, CA.
}

$\mathrm{BN}$ and $\mathrm{SiC}$ did not generate any significant amount of gaseous species as was thermodynamically predicted. However, there were indications of a reaction zone at the interface by SIMS analysis of the $\mathrm{BN}$-coated $\mathrm{SiC}$ coupon and TEM analysis of reacted powders in the Knudsen cell. The reaction can potentially change the interface properties to limit the beneficial effects of the $\mathrm{BN}$ coating. In a long-term exposure, the $\mathrm{BN}$ layer may eventually be depleted.

Acknowledgment: We are grateful to K. L. Luthra of General Electric CR\&D for supplying the BN-coated $\mathrm{SiC}$ and $\mathrm{D}$. R. Hull at NASA-Lewis Research Center for TEM analysis of the carbon-coated coupons.

\section{References}

'D. B. Marshall and A. G. Evans, "Failure Mechanisms in Ceramic-Fiber/ Ceramic-Matrix Composites," J. Am. Ceram. Soc., 68, 225-31 (1985).

${ }^{2}$ L. Filipuzzi, G. Camus, R. Naslain, and J. Thebault, "Oxidation Mechanisms and Kinetics of 1D-SiC/SiC Composite Materials: I, An Experimental Approach," J. Am. Ceram. Soc., 77, 459-66 (1994).

${ }^{3}$ L. Filipuzzi and R. Naslain, "Oxidation Mechanisms and Kinetics of 1D-SiC/ SiC Composite Materials: II, Modeling," J. Am. Ceram. Soc., 77, 467-80 (1994).

${ }^{4}$ J. D. Cawley, O. Unal, and A. J. Eckel, "Oxidation of Carbon in Continuous Fiber Reinforced Ceramic Matrix Composites"; pp. 541-52 in Ceramic Transactions, Vol. 38, Advances in Ceramic-Matrix Composites. Edited by N. P. Bansal. American Ceramic Society, Westerville, OH, 1993.

${ }^{5}$ T. M. Bessman, "SOLGASMIX-PV, a Computer Program to Calculate Equilibrium Relationships in Complex Chemical Systems," Report No. ORNL/TM5775, Apr., 1977

${ }^{6}$ M. W. Chase, Jr., et al. (Eds.) JANAF Thermochemical Tables, 3rd ed., 1985.

${ }^{7}$ A. R. Badzian, T. Niemyski, S. Appenheimer, and E. Olkusnik, "GraphiteBoron-Nitride Solid Solutions by Chemical Vapor Deposition"; p. 747 in Proceedings of the Third International Conference on Chemical Vapor Deposition. Edited by F. A. Glaski. American Nuclear Society, Hinsdale, IL, 1972.

${ }^{8}$ F. Saugnac, F. Teyssandier, and A. Marchand, "Characterization of C-B-N Solid Solutions Deposited from a Gaseous Phase between $900^{\circ}$ and $1050^{\circ} \mathrm{C}$," J. Am. Ceram. Soc., 75 [1] 161-69 (1992).

${ }^{9} \mathrm{~J}$. L. Margrave (Ed.), The Characterization of High Temperature Vapors. Wiley, New York, 1967.

${ }^{10}$ N. S. Jacobson, K. N. Lee, and D. S. Fox, "Reactions of $\mathrm{SiC}$ and $\mathrm{SiO}_{2}$ at Elevated Temperatures," J. Am. Ceram. Soc., 75 [6] 1603-11 (1992).

'IJ. I. Eldridge and F. S. Honecy, "Characterization of Interfacial Failure in SiC Reinforced $\mathrm{Si}_{3} \mathrm{~N}_{4}$ Matrix Composite Material by Both Fiber Push-Out Testing and Auger Electron Spectroscopy," J. Vac. Sci. Technol. A, 8 [3] 2101-106 (1990)

${ }^{12}$ R. T. Bhatt, "Mechanical Properties of SiC Fiber-Reinforced ReactionBonded $\mathrm{Si}_{3} \mathrm{~N}_{4}$ Composites," NASA Technical Memorandum No. 87085, 1985.

${ }^{13}$ C. I. Whitman, "On the Measurement of Vapor Pressures by Effusion," J. Chem. Phys., 20, 161-64 (1952).

${ }^{14} \mathrm{~K}$. Motzfeld, "The Thermal Decomposition of Sodium Carbonate by the Effusion Method,"J. Phys. Chem., 59, 139-47 (1955). 